\title{
Political independence of the South African Reserve Bank: Managing interest rates
}

\author{
Authors: \\ Ewert P.J. Kleynhans ${ }^{1}$ \\ Ryan Meintjes ${ }^{1}$ \\ Affiliations: \\ ${ }^{1}$ School of Economics, \\ North-West University, \\ South Africa \\ Correspondence to: \\ Ewert Kleynhans \\ Email: \\ 11289570@nwu.ac.za \\ Postal address: \\ Private Bag X6001, \\ Potchefstroom 2520, \\ South Africa \\ Dates: \\ Received: 14 May 2013 \\ Accepted: 15 Aug. 2013 \\ Published: 24 Oct. 2013 \\ How to cite this article: \\ Kleynhans, E.P.J. \& \\ Meintjes, R., 2013, 'Political \\ independence of the South \\ African Reserve Bank: \\ Managing interest rates', \\ Acta Commercii 13(1), \\ Art. \#203, 10 pages. \\ http://dx.doi.org/10.4102/ \\ ac.v13i1.203

\section{Copyright:} \\ (C) 2013. The Authors. \\ Licensee: AOSIS \\ OpenJournals. This work \\ is licensed under the \\ Creative Commons \\ Attribution License.
}

Read online:
Purpose: The purpose of this article is to determine whether the South African Reserve Bank (SARB) is politically independent and able to operate without undue external influence.

Problem investigated: The SARB is under increasing pressure to shift its monetary policy stance in order to boost the country's competitiveness. Whether external demands have compromised its independence at times has been the subject of debate.

Methodology: The study comprised a literature review and econometric analysis of the Bank's independence. Movements in interest rates were used as an indicator of dependence. The analysis was between actual interest rates in South Africa over the past two decades, and a model of what interest rates should have been during this period, with reference to Taylor's Rule. Differences between the two were assumed to expose shortcomings in the direction of South Africa's monetary policy and therefore some degree of dependence.

Findings and implications: Movement of the two sets of rates correlated, which suggests SARB independence. The findings did not reveal harmony between the levels of the two sets of rates. However, the latter correlation was not the focus of this study.

Originality and value of the research: This study makes an important contribution, as few authors researched the relationship between interest rates and the SARB's independence scientifically. The study is well timed as the SARB's independence debate has reached concerning levels.

Conclusion: The results suggest almost no level of dependence - which does not necessarily imply that the SARB is entitled to reject all external input, but rather that it can prioritise its objective of price stability over other concerns.

\section{Introduction}

The political independence of the South African Reserve Bank (SARB) is investigated in this article utilising interest rate announcements as an indirect measuring instrument. According to Thirlwall (2006:17), the first step in development planning of a country is to establish a national banking system, comprising a central bank, a commercial banking system and a special development bank. The SARB is South Africa's central bank, a privately owned entity that was given a makeover (after the Currency and Bank Act of 1920) with the enactment of the SARB Act (Act No. 90 of 1989). Later, with the dawning of the new political dispensation in 1994 and the subsequent adoption of the new Constitution in South Africa in 1996, the role of the SARB was firmly entrenched with the adoption of section 223 of the Constitution, the latter being seen as the highest law in the land.

In terms of the SARB Act and the Constitution, the SARB's primary objective is to protect the value of the currency through monetary policy aimed at sustainable economic growth (Henkeman 2010). In section 224 of the Constitution, it is further stated that the SARB must - in pursuit of its primary objective - perform its functions independently and without any fear, favour or prejudice, but that there must be regular consultation between the SARB and the minister of finance.

Although the Constitution asserts the need for the independence of the SARB to insulate it from partisan interference, the monetary authority in South Africa consists of the SARB and the finance ministry-controlled National Treasury. The apparent contradiction in, on the one hand, being independent and, on the other hand, having joint authority with the government's finance ministry over monetary matters started to cause some confusion amongst concerned South Africans and subsequently gave rise to a national debate on the independence of the SARB (Nevin 2007:2).

Whilst there is a need for the SARB and the finance ministry to cooperate, it appears to compromise the SARB's purported independence. It should be noted that the minister of finance is only 
supposed to provide suggestions regarding monetary policy in South Africa. At the end of the day, the SARB must still perform its mandate independently, even if this results in a total disregard for the minister's requests.

However, the commencement of the third millennium has heralded a new era in South Africa in which other parties, such as the finance minister, are making demands on the SARB. In recent years, these demands have become increasingly strident and public, leading many citizens to conclude that the SARB's authority and independence are under threat. For instance, in 2007, the president of South Africa publicly stated that he wanted interest rates to be kept low and the rand (the South African currency) to be maintained at weaker levels (Nevin 2007:2). In 2010, the Congress of South African Trade Unions (COSATU), an alliance partner of South Africa's ruling party, demanded cuts in interest rates in order to (in its view) bring down the inflation rate, in the belief that this would lead to greater competitiveness in the country. (Clearly COSATU does not have economists within its ranks.)

In an act seen as an attempt to assert its independence, the SARB released an official statement clarifying the parameters in which it operates (Creamer 2010:11). Unfortunately, this official statement received little attention. COSATU persisted in its demands that the SARB should change its policy and cut interest rates in order to decrease inflation. COSATU's national spokesperson stated that 'the cautious, conservative, inflation-targeting policy of the SARB is out of sync with the government's policy' (Craven 2011).

At the present time, South Africa has an official inflation target of $3 \%-6 \%$, which the SARB sets out to achieve through interest rate adjustments (Jonsson 2001:243). Therefore, the SARB has the task of keeping inflation under control by guarding against inflation exceeding the $3 \%-6 \%$ range.

Historically, this approach has, given South Africa's persistent inflationary pressures, led to a situation in which the SARB has implemented interest rate adjustments by regularly increasing the bank rate in increments of $0.5 \%$. For instance, from 8 June 2006 until 11 December 2008, the interest rate was increased every six months. Then, at the end of 2008, the SARB suddenly started implementing interest rate cuts. These cuts could have been a reaction to (1) COSATU's demands and the government's publicly expressed concerns that economic growth could be eroded by 'using interest rates as a blunt instrument' (Nevin 2007:2), or (2) the unfolding global financial crisis. In this regard, central banks around the world began to cut interest rates in late 2008 to ease monetary conditions in the face of the global economic slowdown.

Not surprisingly, given the ongoing calls in various quarters for interest rate cuts, the sudden change in the direction of the SARB's interest rate adjustments added fuel to the debate about the its independence, which persists to this day. Things came to a head when COSATU and the government started calling for the SARB to be nationalised (Ndima 2010). Cracks seemed to appear in the wall of the SARB's autonomy, forcing them to ask how independent the SARB really is from the government and its allies, and how much clout the governor of the SARB and the monetary policy committee have in deciding crucial fiscal direction (Nevin 2007:2).

Numerous studies have highlighted the importance of price stability in the management of an economy, and the negative economic consequences that can result from high and volatile inflation levels (Sarel 1996:199). These consequences manifest themselves through several channels. For instance, higher inflation implies greater inflation volatility. This, in turn, causes potential investors to focus more on investing in the short term or hedging against higher inflation, and less on long-term, productive investments. Higher inflation leads to higher nominal interest rates, which stimulate inflows of short-term risk capital. When a climate of high inflation prevails in the long run, inflation as well as currency depreciation expectations become the basis for the decision-making of economic agents. High, and sometimes unforeseen, inflation brings with it several other economic distortions that deal a blow to a country's growth potential, which erodes the value of savings, weakens the tax system, and redistributes income from creditors to debtors.

The SARB's political independence is important here because politicians and their allies may seek to compel the SARB to adopt measures that, although in the short run may boost economic growth, will lead to unwanted higher inflation in the long run. Economic growth will then return to its original level or sink to even lower levels, due to the higher inflation. A sufficient degree of independence from political influences allows the SARB to resist such pressures.

\section{The rationale of this study}

The SARB's political independence is a prerequisite for realising its primary monetary objective, which is to protect the value of the currency (Issing 2003:2) - just like any other central bank. The purpose of this article is to identify any deviation from the desired level of political independence. This will be achieved by focusing on interest rates as an indirect indicator of the extent of the SARB's dependence. In the event that undesirable levels of dependence are uncovered, it would be a signal that the SARB is failing not only in its mandate to operate independently, but also in its contribution to the development of South Africa.

The study comprises two main parts: a literature review on central bank independence, which provides a theoretical backdrop to the problem, and an empirical analysis, which tests the SARB's political independence statistically. The outcome of the study will be of particular interest to those concerned about, and actively involved in, South Africa's economic development process.

\section{Literature review on central bank independence}

Before attempting any statistical analysis, the SARB's independence needs to be examined from a theoretical 
perspective. This will make it easier to gain some knowledge on the subject matter and form expectations with regard to the relationship between the variables and how they contribute in assessing the level of independence.

The literature on the subject can be divided into two groups. The first group of authors studied the legal independence of reserve banks (central banks). There are, however, two problems with using law as an indicator of reserve bank independence. In the first place, the laws are incomplete and cannot explicitly define the limits of authority between the reserve bank and the government. According to Cukierman, Webb and Neyapti (1992:355), these voids are filled by tradition at best and by power at worst. Secondly, the actual practice of measuring legal independence may deviate from the content of the legislation.
The second group of researchers (and by far the majority in the literature) use economic variables to conduct their analysis. Table 1 provides an overview of the various dependent variables used in studies into central bank independence over the past few decades.

Only a few authors have considered the specific relationship between interest rates and reserve bank independence. One of the first attempts was by Barro and Sala-i-Martin (1990). Unfortunately, their research could not prove a clear relationship between ex ante real interest rates (nominal interest rates minus expected inflation rate) and reserve bank independence. Later, Alesina and Summers (1993) attempted to prove a relationship between ex post real interest rates (nominal interest rates minus inflation rate) and bank independence, but just fell short. However, Alesina and

TABLE 1: Variables used in determining central bank independence.

\begin{tabular}{|c|c|c|}
\hline Author & Period & Dependent Variable \\
\hline Bade \& Parkin (1988) & 1972-1986 & Inflation, inflation variability \\
\hline Alesina $(1988,1989)$ & 1973-1985 & Inflation, inflation variability \\
\hline Baro and Sala-i-Martin (1990) & 1953-1988 & Interest rate \\
\hline Grilli et al. (1991) & 1950-1989 & Inflation, growth and variability of growth, output, budget deficit \\
\hline Cukierman et al. (1992) & 1950-1989 & Inflation, inflation variability, reserve bank credit to public sector \\
\hline De Haan \& Sturm (1992) & $1961-1987$ & Inflation, inflation variability, GDP growth rate, budget deficit, reserve bank credit to public sector \\
\hline De Long \& Summers (1992) & 1955-1990 & GDP growth rate/working \\
\hline Alesina \& Summers (1993) & 1955-1988 & $\begin{array}{l}\text { Inflation, inflation variability, variability of growth, unemployment, unemployment variability, GNP growth, interest rate variability, } \\
\text { interest rate }\end{array}$ \\
\hline Cukierman et al. (1993) & 1960-1989 & Output, growth, productivity growth, private investment, interest rate \\
\hline De Haan et al. (1993) & 1979-1989 & Disinflation costs \\
\hline Eijffinger \& Schaling (1993) & 1972-1991 & Inflation, inflation variability, variability of growth, output growth \\
\hline Havrilesky \& Granato (1993) & $1955-1987$ & Inflation \\
\hline Pollard (1993) & 1973-1989 & Budget deficit, variance of deficit \\
\hline Posen $(1993,1995)$ & 1950-1989 & Inflation \\
\hline De Haan \& Siermann (1994) & 1950-1989 & Inflation \\
\hline Eijffinger et al. (1994) & 1977-1990 & Inflation, inflation variability, output growth, variability of growth, interest rate variability, interest rate \\
\hline Fratianni \& Huang (1994) & 1960-1990 & Inflation, inflation variability, output variability output growth \\
\hline Al Marhubi \& Willet (1995) & 1973-1989 & Inflation \\
\hline Cargill (1995) & 1962-1991 & Inflation \\
\hline Cukierman \& Webb (1995) & 1950-1989 & Inflation, inflation variability, output growth, level and variance of interest rates \\
\hline Debelle \& Fischer (1995) & 1960-1992 & Inflation, disinflation costs \\
\hline De Haan (1995) & 1973-1989 & Inflation, inflation variability \\
\hline Eijffinger \& Van Kuelen (1995) & 1982-1993 & Inflation, inflation variability \\
\hline Gartner (1995) & $1966-1988$ & Disinflation costs \\
\hline Walsh (1995) & 1973-1992 & Disinflation costs \\
\hline Loungani \& Sheets (1995) & 1993 & Inflation \\
\hline Bleaney (1996) & 1973-1989 & Inflation, unemployment \\
\hline Fuhrer (1997) & 1950-1989 & Inflation \\
\hline Temple (1998) & 1974-1994 & Inflation \\
\hline Jan Sikken \& De Haan (1998) & 1950-1994 & Budget deficit, monetisation of deficit \\
\hline Posen (1998) & 1950-1989 & Disinflation costs \\
\hline Mangano (1998) & 1980-1989 & Output growth, GDP deflator growth \\
\hline De Haan \& Kooi (2000) & 1980-1989 & Inflation, inflation variability, output growth \\
\hline De Haan \& Sturm (2001) & 1980-1989 & Inflation \\
\hline Brumm (2006) & 1973-1994 & Inflation \\
\hline Meade \& Crowea (2008) & 1987-1994 & Inflation, real GDP/capita, openness, exchange rate regime, democracy \\
\hline Moser \& Dreher (2010) & 1993-2006 & Central bank governor turnover \\
\hline
\end{tabular}

Source: Based on the research of Ćorić, T. \& Cvrlje, D., 2009, 'Central bank independence: The Case of Croatia', Working Paper Series No. 09-09, Faculty of Economics and Business, University of Zagreb, and Eijffinger, S.C.W. \& De Haan, J., 1996, 'The political economy of central bank independence', Special Papers in International Economics No. 19, May GDP, gross domestic product. 
Summers (1993:155), as well as Cukierman et al. (1993), could confirm the inverse relationship between the variability of ex post real interest rates and bank independence. Cukierman and Webb (1995:355) showed the significant influence that political sensitivity has on reserve bank independence, especially if the turnover rate of reserve bank governors is compared with the variability of interest rates. The authors proved that there is higher variability of ex post real interest rates in countries with lower levels of central bank independence.

Eijffinger and De Haan (1996:38) also confirmed the existence of a relationship between inflation and central bank independence. The authors found that greater reserve bank independence prevails in countries with low inflation and therefore higher ex post real interest rates.

The major difficulty in assessing reserve bank independence is that there is no variable in existence that directly measures the level of independence. Furthermore, the tests conducted in the past have consisted of cross-panel data where the independence of reserve banks of different countries were ranked relative to one another, based on variables thought to best declare the level of independence.

Furthermore, when studying the theoretical literature, few applicable pieces of literature could be found because this study goes beyond previous work in two respects. In the first place, this study is country specific. The benefit of focusing on a single country is that discrepancies arising from differences between various countries' political or economic climates are eliminated. An added difficulty for South Africa is that much of the data used in other studies is unavailable. This absence of data makes it difficult to run larger regressions spanning longer periods of time. Furthermore, the test in this study is not designed to confirm or deny an inverse relationship between interest rates and reserve bank independence, as has been the focus of many tests conducted in the past (refer to Table 1). Rather, the aim here is to ascertain whether the differences in movements (not the levels) of actual interest rates and projected interest rates could indicate the presence of political influence. More specifically, the focus of this investigation is whether these differences could be caused by the presence of a particular variable denoting political pressure from the government and/or COSATU.

\section{Methodology employed in the study Modus operandi in constructing the empirical test}

The adjustment of interest rates is one of the primary instruments of the SARB's monetary policy. Metaphorically, the SARB's monetary policy is implemented by an invisible arm. This arm can only do three things: (1) move up - there is a hike in interest rates, (2) move down - there is a cut in interest rates, or (3) stay stationary - interest rates remain unchanged.

The empirical analysis constructed for the purpose of this study consists of two interest rate models.

\section{Model 1: On actual interest rates}

Model 1 (the first part of the analysis) investigates the actual interest rates that have prevailed in South Africa over the past 20 years. The authors set out to determine whether or not announced movements in interest rates correspond with movements indicative of a monetary policy characterised by the absence of fear, favour or prejudice. This school of thought suggests that monetary policy should fundamentally be automatic. In particular, the SARB should be required to follow a series of simple, pre-specified and publicly announced economic rules in setting interest rates.

Model 1 consists of traditional economic indicators of what predicts the movement in interest rates. These indicators could be seen as the inherent muscle that moves the SARB's metaphorical arm freely and independently in its adjustment of interest rates. The a priori expected influences these indicators will have on the movement of the arm are also investigated, bearing in mind that the responsiveness of the interest rate to various economic indicators may actually suggest that the SARB is responding to the government's economic targets. These indicators consist of the following main variables (for the sake of simplicity, this list is by no means exhaustive):

- Exchange rates: Following an exchange rate shock that depreciates the real exchange rate, interest rates should rise due to inflationary pressure.

- Labour cost: Since firms and organisations have to borrow to pay for inputs, their effective labour cost will be higher and profits will decline. This, in turn, will decrease labour's demand for any given real wage. The ultimate effect of this will be an increase in the interest rate, and vice versa.

- GDP: A larger-than-expected increase in the gross domestic product (GDP) is considered inflationary. The SARB may need to intervene and hike interest rates in order to slow the pace of growth. An economic downturn or negative growth, however, may prompt the SARB to cut interest rates in order to stimulate the economy and increase the growth rate again.

- CPI: A higher consumer price index (CPI) is inflationary, requiring interest rates to rise. Likewise, a lower-thanexpected CPI causes interest rates to fall.

- PPI: If the producer price index (PPI) is high, it is considered inflationary, requiring the SARB to raise interest rates.

- Credit extended: Consumer credit data tracks debt levels for motor vehicle financing and commercial banking credit, and is a good indicator of consumer spending in the country. Consumer credit reports are generally considered to have little impact on interest rates. However, with reference to South Africa and its high debt levels (due to acceleration in money supply and credit growth), the SARB has periodically raised interest rates alongside the Treasury's raising of taxes in order to discourage spending and increase savings.

- Consumption: Interest rates are not associated with expected changes in consumption. In other words, the predictable movements that one observes in consumption 
cannot be explained as a rational response to movements in real interest rates. This means that forward-looking consumers do not adjust their consumption growth in response to interest rates, so their inter-temporal elasticity of substitution in consumption must be close to zero.

- Unemployment: A lower-than-expected unemployment rate or declining trend is considered inflationary, requiring an increase in interest rates.

- House prices: Due to the accelerated rise in house prices throughout the world and the fact that this was a strong catalyst in the events leading up to the recent world economic crisis, house prices are considered to be one of the leading economic indicators, and certainly an important indicator within the context of this study. An increase in house prices triggers economic growth and is considered inflationary, which necessitates the raising of interest rates.

The variables listed above can form an effective instrument to determine whether the SARB uses pre-specified economic indicators to automatically adjust interest rates. Insignificant indicators were excluded when preliminary regressions were carried out. Such an exclusion also minimises the risk of bias caused by the potential endogeneity problem (where in this case interest rates could also affect variables such as exchange rates, GDP and prices, for instance).

Another external factor that could influence or even force the movement of the metaphorical arm was measured using a sort of checks and balances approach:

- Pressure groups (x): To give the model greater substance, the media - as an additional independent variable was used as a proxy for measuring the level of activity witnessed within pressure groups. In other words, this variable can indicate whether the SARB follows a series of simple, pre-specified and publicly announced rules in setting interest rates, or rather adjusts interest rates in a specific direction out of fear, favour or prejudice. It may be argued that all significant public demands made by COSATU, other branches of government and even private individuals would be documented in the national newspapers, and that the majority of such demands would amount to calls for the downward adjustment of interest rates.

By examining South Africa's national newspaper archives, the authors tabulated the number of public attacks on the independence of the SARB or demands for specific interest rate adjustments over the past 20 years. To confirm the credibility of the archived information, the results obtained were compared with the number of hits received from an advanced search option on the Internet, a method commended by the Federal Reserve Bank of San Francisco (Walsh 2011). The two sets of results indeed correlated with each other, thereby confirming their consistency and reliability. It should be noted that public demands, expressed through the media, for the lowering of interest rates do not necessarily indicate a lack of independence of the part of the reserve bank. During economic downturns, such calls may be amplified even if the bank has already started an easing cycle. The media indicator was only one variable amongst many, and more than one model was applied in the overall analysis.

This article examines the dependence (or otherwise) of the SARB by building a two-part interest rate function using various determinants of interest rates as prescribed by the literature, as well as other variables that could influence the movement in interest rates. Time series data was used throughout the study. One of the primary objectives in the analysis of time series data is to forecast future values. This study, however, was more interested in finding explanations for the movement (up, down or remaining stationary) than predicting the level of interest rates.

Quarterly data was collected from 1990 to 2010 and used in the regression conventional linear models. It was decided to use quarterly data instead of annual data in order to increase the degree of freedom during the data analysis. Greater degrees of freedom tend to increase the strength of the model.

The authors proceeded by constructing a theory-based model that captures the essence of the determinants of change in the key interest rate. For the sake of simplicity, a broader approach was used in the selection of economic indicators of the movement in South African interest rates. The special variable discussed in the literature review, viz. 'media' as proxy for measuring the activity of pressure groups, was also included.

This initial model, incorporating all the independent variables, can be presented by means of the following equation, with interest rates being the dependent variable:

$\Delta d \_$prime ${ }_{\mathrm{t}}=\beta_{0}+\beta_{1} \Delta$ exchange_rate $_{\mathrm{t}}+\beta_{2} \Delta \mathrm{GDP}_{\mathrm{t}}+$

$\beta_{3} \Delta$ d_labour_cost $+\beta_{4} \Delta \mathrm{PPI}_{\mathrm{t}}+\beta_{5} \Delta$ credit_extended ${ }_{\mathrm{t}}+\beta_{6} \Delta \mathrm{M} 3_{\mathrm{t}}+$

$\beta_{7} \Delta$ prime $_{\mathrm{t}}+\beta_{8} \Delta \mathrm{CPI}+\beta_{9} \Delta \mathrm{d}_{-} \mathrm{CPI}+\beta_{10} \Delta \mathrm{d}_{-}$consump ${ }_{\mathrm{t}}+$

$\beta_{11} \Delta \mathrm{d}$ _unemployment $+\beta_{12} \Delta \mathrm{d}_{-}$housing $\mathrm{t}_{\mathrm{t}}+$

$\beta_{13} \Delta \mathrm{d} \_$media $_{\mathrm{t}}+U_{\mathrm{t}}$

[Eqn 1]

\section{Model 2: On projected interest rates}

The simple monetary policy rule, known as Taylor's Rule, stipulates how much the SARB should change the nominal interest rate in response to divergences of actual inflation rates from target inflation rates, and of actual GDP from potential GDP (Taylor 1993:202). Although some deviations from the rule are in evidence, a large body of literature has applied Taylor's Rule to many countries and sets of circumstances. Orphanides (2001:966) notes that Taylor's Rule not only describes a reserve bank's monetary policy, but also acts as a useful benchmark for judging whether current policy is appropriate.

With reference to interest rates, therefore, it is argued that the difference between Taylor's Rule's projected interest rate and the actual interest rate produces a 'grey area' encompassing the error experienced in the direction of South Africa's monetary policy. In this study, the grey area could be caused by external influences on the movement of interest rates, which indicates some level of dependence. 
This study uses Taylor's Rule as an indicator of what the movement in interest rates should have been, and compares the result with the actual announced interest rate adjustment for the period in question. Therefore, the appropriate interest rate is calculated with Taylor's Rule requiring that the real interest rate $\left(R_{\mathrm{t}}^{*}-\pi_{\mathrm{t}}\right)$ responds to (1) the difference between current output $\left(Y_{\mathrm{t}}\right)$ and full employment output $\left(\mathrm{Y}^{*}\right)$ and $(2)$ the difference between current inflation $\left(\pi_{t}\right)$ and targeted inflation $\left(\pi^{*}\right)$ (Abel \& Bernanke 2001:545). On this basis, if the South African economy is overheating, with output growing faster than full employment output and inflation rising, then Taylor's Rule requires the monetary authority (SARB) to raise the interest rate. If the economy is sluggish, with output and inflation decreasing, then Taylor's Rule requires the monetary authority to lower the interest rate. It then follows that a consistent monetary policy rule is established. It is therefore possible to assess whether the SARB's metaphorical arm moves freely in the adjustment of interest rates using Taylor's Rule.

Model 2 consists of the same dependent variable used in Model 1, namely interest rates, but the actual interest rates were then regressed against what the interest rates should be as prescribed by Taylor's Rule. Currently, there is no historical data in South Africa pertaining to the application of Taylor's Rule for the period being considered. The authors proceeded to develop their own set of values according to the prescribed formula of Taylor. The results obtained were then used as the first explanatory variable. The rule can be written as follows:

$R_{\mathrm{t}}=\pi_{\mathrm{t}}+\pi^{*}+\alpha\left(\pi_{\mathrm{t}}-\pi^{*}\right)+\beta\left(Y_{\mathrm{t}}-Y^{*}\right)$

The following values were assumed for the inputs in the model:

- $R^{*}{ }_{\mathrm{t}}$ is the equilibrium real short-term interest rate in period $t$.

- $\pi_{t}$ is the rate of price inflation at period $t$.

- $\pi^{*}$ is $4.5 \%$, the mid-point of the SARB's targeted inflation rate of $3 \%-6 \%$.

- $Y_{\mathrm{t}}-Y^{*}$ is the output gap at period $t$, measured as a percentage deviation of actual gross domestic product from potential gross domestic product.

- Parameters $\alpha$ and $\beta$ are assumed to be equal to 0.5. (Although 0.5 is recommended for the United States, this value has been accurately applied to the South African situation.)

The appropriate rate of interest was then calculated. The results were subsequently regressed against the movement in the actual interest rates observed over the same period of time. This model can be presented by the following equation:

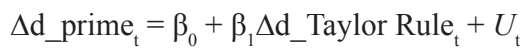

[Eqn 3]

From the regression results, the authors analysed, under the ceteris paribus condition, the reaction of interest rates to changes in the independent variables. In this study, conventional linear models were used, and the independent variables were included under strict prescription from the literature reviewed. In order to prevent model underspecification (i.e. the risk of important economic variables being excluded from the model), as many variables as possible were initially used in Model 1 . The variables that proved to be statistically insignificant were then dropped from the final model.

Analysis of variables does vary with the type of model specification used (Gujarati 2006:336). Model specification is also important since a correctly specified model exhibits qualities such as parsimony (the model is kept as simple as possible), goodness of fit (the $R^{2}$ is as high as possible), identifiability (the estimated parameters have unique values, i.e. only one estimate per parameter), theoretical consistency (coefficients have the correct signs and the model has its foundation in economic theory) and predictive power (predictions of the model originate from actual experience).

Traditional measures such as the $R^{2}$ and adjusted $R^{2}$ were examined because they indicate the model's ability to explain variations in the dependent variable - in other words, the 'goodness of the fit' of the model. Traditional $t$-statistics measure individual variable significance, but probability values ( $p$-values) offer a more comprehensive measure and were used in the analytical portion of this study. These standard functions of econometric analysis were performed according to time series-specific analysis as well. In addition, this study involved extensive scrutiny of the variables, with special attention being paid to matters such as stationarity.

\section{Research hypothesis}

The aim of this study was to test the SARB's political dependence statistically. To this end, comprehensive empirical testing was conducted. An initial regression was carried out in order to ascertain whether the SARB's monetary policy committee uses traditional economic indicators to steer interest rate adjustments. On the strengths of the literature review, the main independent variables - which should determine the movement of the interest rate - were GDP, PPI, exchange rates, CPI, M3, credit extended, consumption, unemployment, house prices and labour cost. The authors decided to use first differences (instead of co-integration analysis) for house prices, credit extended, CPI, consumption, unemployment and labour cost. The reason for differencing was to remove the trend component from the time series completely, rendering it stationary (Asteriou \& Hall 2007:17). This approach also resulted in a final regression showing a better fit and higher significance.

After the construction of a regression with the respective variables, an interest rate hypothesis test was conducted. The null and alternative hypotheses used to test the premise that there is no relationship between the dependent variable and the independent variables were:

$\mathrm{H}_{0}$ : coefficient $=0$ (statistically insignificant)

$\mathrm{H}_{1}$ : coefficient $\neq 0$ (statistically significant) 
The hypothesis testing indicates whether the coefficient of any variable equals zero, in which case it would be statistically insignificant in the sense that there would be no relationship between the independent and dependent variables. On the other hand, a variable with a non-zero coefficient indicates that some relationship between the two variables does exist.

Tests for stationarity were then carried out to confirm that the regression results were credible and non-spurious. The tests included correlogram analysis and Dickey-Fuller tests for unit roots. The empirical results obtained in this study are reported in the following section.

\section{Empirical results on central bank independence}

Several regressions were estimated with different combinations of variables before a final model was constructed. A priori expectations regarding the signs of coefficients have already been discussed in the literature review in this article. These expectations were formed through economic reasoning, and the estimated coefficients and its relevant statistics will now be interpreted. The regression results are shown in Table 2.

The estimated constant of the regression given in Table 2 shows that not all of the explanatory variables explain the interest rate adjustments. By examining the $p$-values, it emerged that exchange rate, PPI, M3 and labour costs were the only statistically significant variables at a $5 \%$ level. The aforementioned variables are significant for all conventional significance levels, because the null hypothesis is rejected at all levels above $0.2 \%$. Having insignificant predictors in the regression does not pose any reason for concern because this occurrence could be explained in economic terms. From the literature review it was established that it is possible for certain indicators to have no relation to interest rates if they appear next to other explanatory variables (e.g. consumption).

After determining which coefficient has the lowest standard error in combination with the lowest $p$-value, it became apparent that the first difference of CPI was the most significant predictor of interest rates overall in the model. CPI also showed the highest $t$-value.

TABLE 2: Model 1: Dependent Variable: interest rates.

\begin{tabular}{lllll}
\hline Variable & Parameter estimate & Standard error & $\boldsymbol{t}$-Value & $\boldsymbol{P r} \boldsymbol{>}|\boldsymbol{t}|$ \\
\hline Intercept & -0.15240 & 0.06239 & 2.44 & 0.0174 \\
d_media & 0.00709 & 0.00412 & 1.72 & 0.0898 \\
exchange_rate & -0.00262 & 0.00116 & -2.26 & 0.0272 \\
GDP & 0.00129 & 0.00318 & -0.40 & 0.6870 \\
d_labour cost & -0.45035 & 0.29423 & -1.53 & 0.1309 \\
PPI & 0.00259 & 0.00120 & 2.16 & 0.0343 \\
Credit extended & 0.00076421 & 0.00156 & 0.49 & 0.6260 \\
M3 & 0.00379 & 0.00193 & 1.97 & 0.0537 \\
CPI & 0.13148 & 0.27823 & 0.47 & 0.6382 \\
d_CPI & 0.06028 & 0.01574 & 3.83 & 0.0003 \\
d_consumption & -0.07151 & 0.19609 & -0.36 & 0.7166 \\
d_unemployment & 0.00576 & 0.05350 & 0.11 & 0.9146 \\
\hline
\end{tabular}

Source: Authors' own analysis
Model: $\operatorname{Pr}>F, 0.0001 ; R^{2}, 0.5918$; Adjusted $R^{2}, 0.5128$.

Model: $\mathrm{Pr}>\mathrm{F}, 0.0001 ; R^{2}, 0.5918$; Adjusted $R^{2}, 0.5128$

$\mathrm{GDP}$, gross domestic product; PPI, producer price index; $\mathrm{CPI}$, consumer price index; $d$, first differences.
From the statistically significant variables it can be inferred that the exchange rate variable has a negative coefficient $(-0.00262)$, indicative of an inverse relationship with interest rates. That is, a $1 \%$ decrease in the exchange rate of the South African currency will decrease interest rates by $0.2 \%(20$ basis points). This is not in line with the a priori expectations. According to Halvorsen's theory (2009:73), following an exchange rate shock that depreciates the real exchange rate, interest rates should rise again.

The PPI displayed a very similar pattern since the coefficient confirms economic theory and is positive (0.00259). This shows that a $1 \%$ increase in the PPI will also change the interest rate by 20 basis points, but this time in the upward direction: a $0.2 \%$ increase. This value is accurate since its standard error is small (0.00120) and its $p$-value is low (0.0343).

The coefficient on the M3 money supply (0.00379) is reliable as a predictor of the interest rate since it has a small standard error (0.00193) and a somewhat low $p$-value of (0.0537). From the literature reviewed, the expectation was that interest rates should have a positive relationship with M3. This is confirmed by the results: a 1\% increase in M3 will cause a $0.3 \%$ increase (30 basis points) in interest rates.

The first difference of CPI has a positive coefficient (0.06028) in the model, revealing that it has a positive relationship with interest rates. The standard error of this coefficient (0.01574) is fairly small and the $p$-value is very low (0.0003), showing that the null hypothesis of almost no relationship can be rejected at all significant levels.

If it can be proven that the media variable is insignificant, then this will prima facie prove that the SARB is independent. The media variable - even its first difference - displays no pattern or relationship with the current interest rates in South Africa. The $p$-value is high (0.0898), rendering this variable statistically insignificant and therefore useless. The $R^{2}(0.5918)$ and adjusted $R^{2}(0.5128)$ values are relatively high for the type of test conducted, indicative of a good fit for the model.

Considering the statistical significance of the variables in Model 2, it can be seen that Taylor's Rule is statistically significant at an extremely low $p$-value (0.0001), showing that the null hypothesis of almost no relationship must be rejected at all significant levels. Taylor's Rule has a positive coefficient (0.147), and therefore forms a positive relationship with interest rates. That is, a 1\% increase in Taylor's Rule's result will increase interest rates by $14.7 \%$. It seems as if there is a large difference in South Africa's actual interest rate and what the interest rate should be according to Taylor's Rule which, according to the a priori expectations of the literature review section in this article, should not be the case. However, calculations carried out above must allow for errors in measurement, as well as expectations of future interest rate movements. In this study, a margin of 50 basis points $(0.5 \%)$ was considered to be sufficient to cater for any measurement errors and expectation variances. This is also 
in line with the high standard error ( 24 basis points) obtained in the regression results for Taylor's Rule (see Table 3). This big difference could also possibly be explained by the SARB's reaction to the government targets, indicating the presence of political dependence.

From Figure 1, it can be concluded that movement in actual interest rates corresponds with the movement of interest rates according to Taylor's Rule (it should be remembered that this study is only concerned with the adjustment to, and not the level of, interest rates). If this study were concerned with the difference in the levels of interest rates, Figure 1 would suggest evidence of a lack of independence because of the significant gap towards the end of the sample. In fact, actual interest rates are well below those implied by Taylor's Rule, which may suggest that the SARB was under pressure to keep interest rates lower than usual towards the end of the period. Nevertheless, there is a correlation between the movement in actual and Taylor's Rule's interest rates, which implies independence. Furthermore, the $R^{2}(0.3380)$ and adjusted $R^{2}(0.3196)$ values are low even for the type of test conducted, indicative of an inferior fit for the model. The low adjusted $\mathrm{R}^{2}$ could, however, be caused by the absence of the lagged variable of the change in interest rates. The importance of the inclusion of this variable remains unclear - especially when some authors, such as Rudebusch (2002:1164), criticise the conventional wisdom and claim that the interest rate smoothing behaviour at quarterly frequencies is just an illusion. In any event, Taylor's Rule and all the significant variables of Model 1 regressed against actual interest rates have a far larger $R^{2}(0.6183)$.

Tests for stationarity were also conducted in all the above regressions using the Dickey-Fuller test, taking first differences and analysing correlograms. The results concluded that these time series are co-integrated. In other words, the regression

TABLE 3: Model 2: Dependent variable: Interest rates analysis of variance.

\begin{tabular}{lllll}
\hline Variable & Parameter estimate & Standard error & $\boldsymbol{t}$-Value & $\operatorname{Pr} \boldsymbol{| \boldsymbol { t } |}$ \\
\hline Intercept & -0.00798 & 0.00639 & -1.25 & 0.2158 \\
d_Taylor & 0.14700 & 0.02437 & 6.03 & $<.0001$ \\
\hline
\end{tabular}

Source: Authors' own analysis

Model: $\operatorname{Pr}>F=0.0001 ; R^{2}, 0.3380 ;$ Adjusted $R^{2}, 0.3196$

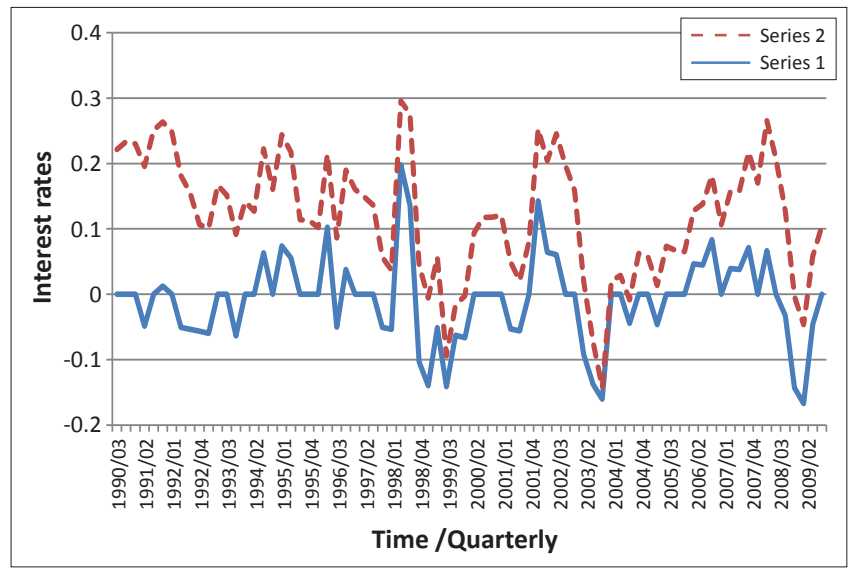

Source: Authors' own analysis

FIGURE 1: Actual interest rates (Series 1) and interest rates proposed by Taylor (Series 2). results are not spurious. Therefore, provided that the regression analysis carried out was economically sound and the residuals from the regressions are stationary, traditional regression methodology is still appropriate for time series data. If the residuals were non-stationary, then the regression with first differenced variables would have to be conducted, at the cost of losing some information on the variables.

The results of the final regression proved to be economically viable, and therefore the analysis of the respective variables is correct. It can be concluded, then, that the study has succeeded in fitting a simple, yet statistically significant, monetary policy regression with Model 1 and that the projected interest rates represented in Model 2 have a good fit.

Based on the aforementioned regression depicted in Model 2 , and compared with the results in Model 1, it seems that the SARB's metaphorical arm does move independently without fear, favour or prejudice. These findings are discussed in the following section, and some recommendations are presented.

\section{Conclusion and future research directions}

Recent events in South Africa suggest that the government and its allies are exerting greater influence in terms of how the economy should be managed, at the expense of the SARB's independence. The country's Constitution confers an important responsibility on the SARB to carry out its mandate without political interference, but seems to leave the door open for the government to influence monetary policy. However, whether that influence extends to direct interference is debatable.

With a view to contributing to the independence debate, this article attempted to determine whether the metaphorical arm of the SARB moves freely without fear, favour or prejudice, or whether the movement depends on external political factors. The results obtained showed that there is almost no level of dependence. Interestingly, these findings come amidst continuous threats to the SARB's independence. The notion of reserve bank independence underlying this study is not unconditional independence from government, but rather independence to pursue the SARB's constitutional objective of price stability, even at the expense of other objectives that are more important to the political authorities. One must, however, also bear in mind that although external pressure may place the reserve bank's independence in jeopardy, there could be some value in these external parties' objectives or requests.

The government has expressed its concerns that liberal interest rate adjustments over successive years could prove to be a one-way, upward stream demanding more 'creative ways to address the problem' of inflation (Nevin 2007:2). COSATU, in turn, has demanded a complete overhaul of the current inflation targeting policy in favour of a monetary policy focusing on the strength of the rand, because this will lead to greater competitiveness (Isa 2010). 
Greater competitiveness brought about by stable prices evidenced in low inflation and stable currency values and financial systems - is important for the economic well-being of the country (Mnyande 2010:2), and goes to the core of what the SARB is doing to contribute to South Africa's sociodevelopmental agenda. However, this does not mean that any third party - especially the government - may prescribe interest rate adjustments in line with what they believe will boost competitiveness.

A possible monetary policy that would influence the strength of the rand is an exchange rate policy. The SARB's current stance regarding the exchange rate is that the value of the rand will be best protected through the consistent application of anti-inflation policies, as this brings stability to the average value of the rand against the currencies of South Africa's trading partners (Halvorsen 2009:73). In theory, this approach should appeal to trade unions such as COSATU. A possible step to take within the context of an exchange rate policy is to fix a specific exchange rate for the rand. This, however, will not be efficient because the variables that influence the balance of payments are continuously in flux, making it necessary for the exchange rate to remain flexible (Department of Finance, 2010).

A further challenge is that the South African government is itself not too sure what shape the country's monetary policy should take. For instance, the political authorities have repeatedly stated in the past that they are committed to phasing out exchange rate controls in a prudent manner. In line with this commitment, the financial rand was abolished in 1995 (Mnyande 2010:3). Now, though, they want to phase out inflation targeting in favour of an exchange rate policy. This does not make sense and jeopardises the SARB's independence unnecessarily.

The main benefit associated with the current inflation targeting policy is that it has made interest rates and spot exchange rates more market related, and this has encouraged private entities to develop the forward cover market. According to Fischer (1995:24), inflation targeting leads to more certainty about price levels in the foreseeable future, but unfortunately at the expense of greater certainty about price levels in the more distant future.

Different monetary policy approaches (e.g. following rules or discretion) have their own advantages and disadvantages. The most efficient monetary policy, therefore, ought to take the best from each policy type and combine them into one eclectic and pragmatic approach. An easy way of doing this is to adopt a monetary policy based on discretion rather than a rule (in the SARB's case, the rule of keeping inflation between $3 \%$ and $6 \%$ ). With discretion, the SARB would have no binding rule to follow, which would make it easier to intervene independently in the economy. This, in turn, would safeguard the desired level of independence, because the lack of a credible commitment mechanism would prevent political authorities from forming inflation expectations. Rather, they would be forced to simply accept the outcome of interest rate announcements (Weerapana 2005:2).
In a study of this sort, small problems can occur. For instance, endogeneity is a potential problem when calculating Taylor's Rule's interest rate. The projected value obtained is statistically a weighted average of the inflation rate and output gap, which could be affected by the actual interest rate. In light of this and other small limitations of this study, the authors offer suggestions for future research. Firstly, instead of conducting a country-specific test, as proposed in this article, the same test could be applied to different countries. The results obtained from each country could then be ranked relative to those of other countries. Secondly, additional political variables could be added to the test, for example, the government's influence when the governor and deputy governors of the SARB are appointed or the prescribed legal procedures involved in removing these governors and deputy governors or perhaps even transparency in how the government obtains its finance. It may also be useful to estimate the coefficient of Taylor's Rule in a sub-period when there was relative consensus about the independence of South Africa's monetary authority.

\section{Acknowledgments Competing interests}

The authors declare that they have no financial or personal relationship(s) that may have inappropriately influenced them in writing this article.

\section{Authors' contributions}

The authors worked together doing the analysis, literature study and writing and preparation of the manuscript. E.P.J.K. (North-West University) was the project leader, having a PhD in Economics, whilst R.M. (North-West University), having both an honours BCom degree in Economics and an LLB, assisted not only in the econometric analysis, but also gave valuable contributions regarding the legislative aspects.

\section{References}

Abel, A.B. \& Bernanke, B.S., 2001, Macroeconomics, 4th edn., Addison Wesley, Boston.

Alesina, A. \& Summers L.H., 1993, 'Central bank independence and macroeconomic performance: Some comparative evidence', Journal of Money, Credit and Banking 25(2), 155. http://dx.doi.org/10.2307/2077833

Asteriou, D. \& Hall, S.G., 2007, Applied econometrics: A modern approach, Palgrave Macmillan, New York. PMCid:PMC1868797

Barro, R. \& Sala-i-Martin, X. 1990, 'World real interest rates', in O. Blanchard \& S. Fischer (eds.), NBER Macroeconomics Annual, pp. 15-74, MIT Press, Cambridge, MA.

Creamer, T. 2010, 'Cosatu proposes radical change to SA's economic medicine', Economic Policy, 14 September, viewed 26 August 2013, from http://www.engineeringnews. co.za/article/cosatu-proposes-radical-change-to-sas-economic-medicine-2010-09-14

Craven, P. 2011, 'COSATU bitterly disappointed at repo rate freeze', statement issued by Patrick Craven, COSATU national spokesperson, 24 March, viewed 24 August 2013, from http://www.politicsweb.co.za/politicsweb/view/politicsweb/en/page 71654 ?oid $=227805 \&$ sn $=$ Detail\&pid $=71654$.

Cukierman, A., Kalaitzidakis, P., Summers, L.H. \& Webb, S.B., 1993, 'Central bank independence, growth, investment, and real rates', Carnegie-Rochester Conference Series on Public Policy No. 29, 95-140, Autumn.

Cukierman, A. \& Webb, S.B., 1995, 'Political influence on the central bank: International evidence', World Bank Economic Review 9(3), 397-423. http://dx.doi.org/10.1093/ wber/9.3.397

Cukierman, A., Webb, S.B. \& Neyapti, B., 1992, 'Measuring the independence of central banks and its effect on policy outcomes', The World Bank Economic Review 6(3), 353-398. http://dx.doi.org/10.1093/wber/6.3.353

Department of Finance, 2010, Growth, employment and redistribution: A macroeconomic strategy, Government Printers, Pretoria.

Eijffinger, S.C.W. \& De Haan, J., 1996, 'The political economy of central bank independence', Special Papers in International Economics No. 19, May. 
Fischer, S., 1995, 'The unending search for monetary salvation', NBER Macroeconomics Annual 10(1995), 275-286. http://dx.doi.org/10.2307/3585118

Gujarati, D., 2006, Essentials of econometrics, McGraw-Hill, New York.

Halvorsen, J.I., 2009, 'Essays on economic fluctuations in an open economy', PhD thesis, Department of Economics, Norwegian School of Economics and Business Administration, Bergen, Norway.

Henkeman, S., 2010, Press release (2010-01-25) on the nationalisation of the South African Reserve Bank, viewed 25 February 2011, from http://www.reservebank. African Reserve Bank, viewed 25 February 2011, from http://www.reservebank.
co.za/internet/publication.nsf/WCEV/37353CCDD7AE9466422576B600609314/? co.za/internet/pub

Isa, M., 2010, 'COSATU's rand call to be hottest debate but devising a policy is a fraught exercise', Business Day, 16 September, viewed 20 August 2013, from http://www. businessday.co.za/articles/Content.aspx?id=121109

Issing, O., 2003, Considerations on monetary policy strategies for Accession Countries. European Central Bank, viewed 23 August 2013, from http://www.ecb.int/press/ $\mathrm{key} /$ date/2003/html/sp030228.en.html

Jonsson, G. 2001. 'Inflation, money demand, and purchasing power parity in South Africa', IMF Staff Papers 48(2), 243.

Mnyande, M., 2010, Relevance of the South African Reserve Bank to the development agenda, SARB, Pretoria, viewed 12 February 2011, from http://www.reservebank. co.za/internet/Publication.nsf/LADV/2B3C9098FA1D858642257700002E4FE7/\$F ile/Dr+Mnyande+Breakfast+Talk.pdf
Ndima, G., 2010., YCL backs ANC calls for nationalisation of Reserve Bank, viewed 26 August 2013, from http://www.politicsweb.co.za/politicsweb/view/politicsweb/ en/page71627?oid $=157495 \&$ sn=Detail \&pid $=71627$

Nevin, T., 2007, 'How independent is the South African Reserve Bank?', African Business, 1 June, viewed 24 November 2010, from http://findarticles.com/p/articles/mi qa5327/is_332/ai_n29360239/

Orphanides, A., 2001, 'Monetary policy rules based on real-time data', American Economic Review 91(4), 964-985. http://dx.doi.org/10.1257/aer.91.4.964

Rudebusch, G.D., 2002, 'Term structure evidence on interest rate smoothing and monetary policy inertia', Journal of Monetary Economics 49(6), 1161-1187. http:// dx.doi.org/10.1016/S0304-3932(02)00149-6

Sarel, M., 1996, 'Nominal effects of inflation on economic growth', International Monetary Fund Staff Papers 43(1), 199-215. http://dx.doi.org/10.2307/3867357

Taylor, B.J., 1993, 'Discretion versus policy rules in practice', Carnegie-Rochester Conference Series on Public Policy No. 39, Stanford University, pp. 195-214.

Thirlwall, A.P., 2006, Growth and development with special reference to developing economies, Palgrave Macmillan, England.

Walsh, C., 2011, email, 09 September 2011,walshc@ucsc.edu

Weerapana, A., 2005, Rules vs. discretion, Wellesley College, Wellesley, MA, viewed 26 March 2011, from http://www.wellesley.edu/Economics/weerapana/econ331/ econ331pdf/lect331-11.pdf 